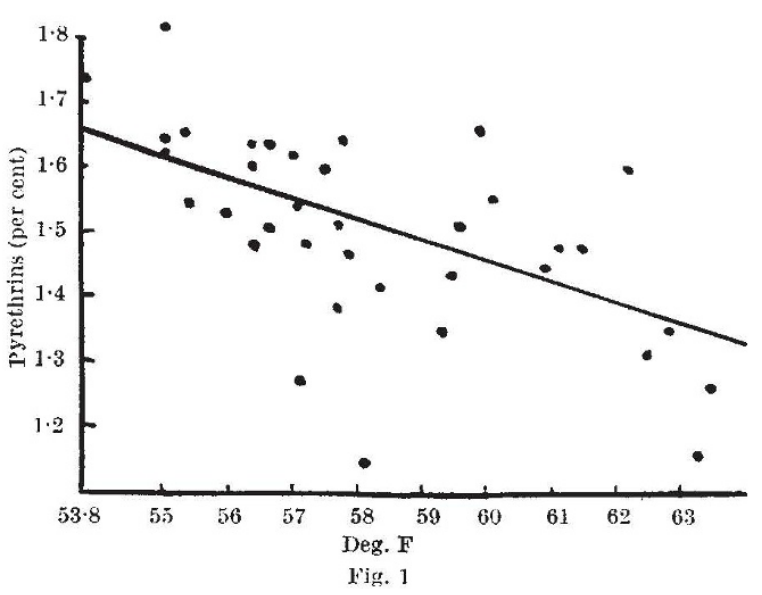

pyrethrins content for an increase by $1^{\circ} \mathrm{F}$ was 0.03 per cent (Fig. 1).

The regression line was calculated on the formula:

$$
Y=a+b x
$$

where $a=1.503$ and $b=-0.03447$.

It has been observed ${ }^{1}$ that the content of pyrethrins on the whole increases as the plant is cultivated at higher altitudes. The regression points at the temperature variation as possibly the main reason for this phenomenon. It is not assumed here that there are no other contributory factors, but it may be more difficult to define them.

Glover ${ }^{3}$ has shown that bud initiation also depends to a large extent on a 'chilling' effect, which explains why flowering, in general, is more prolific at the higher altitude levels and the cultivation of pyrethrum below a certain altitude becomes uneconomic as many plants turn 'blind'. He concluded that flower bud initiation was inhibited if plants were exposed to mean temperatures of $75^{\circ} \mathrm{F}$ for periods exceeding one week.

It appears therefore that pyrethrum depends to a very large degree on temperature effects for flower yield as well as for the production of the toxic agents.

Pyrethrum Board of Kenya,

U. Kroli. Nakuru, Kenya.

${ }^{1}$ Gaddum, E. W., Aun. Rep. Senior Agric. Officer (Pyrethrum) in Ann. Rep. Dept. Agric., Kenya, 80 (1949).

${ }^{2}$ Gaddum, E. W., Ann. Rep. Senior Agric. Officer (Pyrethrum) in Ann. Rep.

${ }^{3}$ Glover, J., Ann. Bot., N.S., 19, 138 (1955).

\section{Frost Injury as a Predisposing Factor in Blossom Blight of Pear caused by Pseudo- monas syringae van Hall}

BACTERIAL blossom blight of pear is widespread in England, but it differs in severity between seasons and orchards. These differences do not appear to be related to the supply of inoculum, for recent work suggests that Ps. syringae is universally distributed on pear trees as the dominant component of the surface microflora. Orchard observations over several years have implicated frost injury to the blossoms as a major predisposing factor in the disease, and we have now confirmed this experimentally.

Potted glasshouse trees of the variety 'Conference' were transferred in full bloom to a special freezing chamber ${ }^{1}$ and thermocouples inserted into solected blossoms to record their temperatures ${ }^{2}$. The blossoms were supercooled to between $-1^{\circ} \mathrm{C}$ and $-2^{\circ} \mathrm{C}$ until a sudden slight rise in temperature indicated the formation of ice crystals in the tissues. After further treatment for $10-15 \mathrm{~min}$, the trees were allowed to regain ambient temperatiue. They were then sprayed from a scent spray with bacteria $\left(10^{8}\right.$ cells $/ \mathrm{ml}$. in aqueous suspension $)$ or with sterile water, and the blossoms enclosed in polythene film to maintain humidity (Exp. 1). In two further experiments on potted trees in full bloom (Exp. 2) and cut-branches taken from field trees at the petal fall stage (Exp. 3) the procedure was the same, except that inoculum or water was applied under pressure from a paint gur.

In a few blossoms frost treatment caused browning of the tissues at the base of the styles; in the majority, how. ever, the injury was slight and involved no more than a. temporary lifting of the 'skin' of the receptacles and pedicels due to separation of the hypodorm from the under. lying cortical cells ${ }^{4}$. Two types of infection wore induced in blossoms: (1) Incipient infections in the calyx cup, probably occurring through the nectaries, and not related to the pro-inoculation treatment. (2) Severe and extensive infection of the receptacles and pedicels, killing the blossoms and resulting in symptoms typical of blight in the field. The percentages of the latier 13 disys after treatment are shown in Table 1.

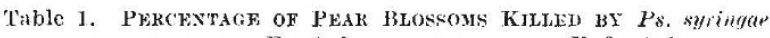

$$
\begin{aligned}
& \begin{array}{ccccc} 
& \multicolumn{2}{c}{\text { Frosted }} & \multicolumn{2}{c}{\text { Cufrosted }} \\
\text { Exp. } & \text { Inoculum } & \text { Water } & \text { Inoculum } & \text { Water } \\
1 & 33 & 0 & 0 & 0 \\
2 & 94 & 0 & 51 & 0 \\
3 & 74 & 62 & 0 & 0
\end{array}
\end{aligned}
$$

With inoculum under pressure some blossom was killed on unfrosted trees of Exp. 2, although much less than on the frosted trees. The symptoms were also less severe. the infection spreading into only 18 per cent of the fruiting spurs compared with 82 per cent on the frosted trees.

The symptoms induced on eut branches by spraying with water after frost treatment (Exp. 3) were due to large natural populations of Ps. syringae which were found to be present on the leaves and blossoms when the branches were brought in from the field. The pathogen was not found on the leaves of the glasshouse trees, and spraying with water after frost treatment had no effect.

We thank Dr. Irena Modlibowska for advice and help with the frost treatments.

$$
\text { C. G. Panagopotlos }
$$$$
\text { J. E. Crosse }
$$

East Malling Research Station, Maidstone, Kent.

1 Slater, C. H. W., Rep. East Malling Res. Sta. for 19.56, 93 (1957).

'Slater, C. H. W., J. Sci. Instrum., 30, 293 (1953).

3 Modlibowska, I., J. Hort. Sci., 37, 249 (1962).

- Modlibowska, 1., J. Pomol., 22, 46 (1946).

\section{Taxonomic Relationships of Stictonetta naevosa (Gould)}

THE systematic position of the freckled duck Stictonetta naevosa (Gould), Anatidae, of Australia has long been uncertain. In the most recent comprehensive investigations of the taxonomy of the family Anatidae ${ }^{1,2}$, based on behavioural characters as well as what were presumed to be non-adaptive anatomical features, including the structure of the trachea and syrinx, tarsus and the colour pattern of the downy young, three sub-families were recognized: Anseranatinae (magpie goose), Anserinae (swans, geese, and tree-ducks) and Anatinae (ducks). These authors recognized that Stictonetta possessed several features characteristic of the Anserinas, for example, the reticulate tarsus, and the lack of bulla, speculum and sexual dimorphism; but, as there was no information available on the bird's behaviour nor on the plumage pattern of its downy young, they preferred to consider it. tentatively, an aberrant member of the Anatinae. Johns. gard ${ }^{3}$, considering the anatomical analysis of waterfowl of Verheyen ${ }^{4}$, speculated whether the bird could really be Anserinae. Recent work in the field and with captive birds now enables the species to be classified with more confidence.

The downy young of Stictonetta are light grey in colour and darker above than below. The throat is slightly 